\title{
TOPOGRAPHIC INSPECTION AS A METHOD OF WELD JOINT DIAGNOSTIC
}

\author{
Jolanta B. Krolczyk, Bartosz Gapinski, Grzegorz M. Krolczyk, Ivan Samardzic, Radoslaw W. Maruda, \\ Kamil Soucek, Stanislaw Legutko, Piotr Nieslony, Yashar Javadi, Lubomir Stas
}

Preliminary notes

The paper demonstrates a topographic inspection in the specific context of three kinds of inspection methods of austenitic stainless steel welds. Visual and metrological inspection was analysed during tungsten inert gas (TIG) welding tests, showing the non-destructive techniques: X-ray, computed tomography, and surface profilometry. The article is a response to the lack of information, especially in the area of non-destructive techniques suitable for wide practical application. The Paper presents advantages and drawbacks of the analysed diagnostic methods and a classification of conventional and specific welded joint flaws. The most important defect in practical applications determining reliability of a welded joint is cracks. This kind of diagnostic is based on the obtained information about anisotropic and inhomogeneous volume under consideration in the heat-affected zone of a weld.

Keywords: computed tomography; non-destructive techniques; profilometry; topography inspection; weld quality; X-ray

Topografsko ispitivanje kao metoda za dijagnosticiranje stanja zavarenog spoja

Prethodno priopćenje

U radu se demonstrira topografsko ispitivanje u specifičnom kontekstu triju vrsta inspekcijskih metoda zavara od austenitnog nehrđajučeg željeza. Vizualna i metrološka kontrola provedena je tijekom ispitivanja zavarivanja TIG postupkom, primjenom ne-destruktivnih metoda: rendgensko ispitivanje, kompjuterizirana tomografija i profilometrija površine. Rad je reakcija na nedostatak informacija, posebice u području ne-destruktivnih metoda prikladnih za široku primjenu u praksi. U radu se prezentiraju prednosti i nedostaci analiziranih dijagnostičkih metoda i klasifikacija uobičajenih i specifičnih mana zavarenog spoja. Najvažnija neispravnost u praktičnim primjenama kod određivanja pouzdanosti zavarenog spoja su pukotine. Ova vrsta dijagnoze zasnovana je na dobivenim podacima o promatranom anizotropskom i nehomogenom volumenu u dijelu zavara pod utjecajem topline.

Ključneriječi: kvaliteta zavara; ne-destruktivne metode; profilometrija; topografski nadzor; računarna tomografija; X-zraka

\section{Introduction}

The present trend in manufacturing demands the joining or welding of materials that are capable of ever increasing stresses. Unfortunately, problems arising due to poor joint quality are generally caused by the manufacturers who limit the application of welding. The quality of a welded joint primarily depends on the weld bead shape and weld microstructure influenced by the process parameters [1]. There are also other reasons for the formation of flaws. According to Sazonov, [2] in welding process many diversified flaws of welded joints can be observed, such as the conventional: cracks, pores, shrinkage of cavities, enhanced hardness, growth of grains, nonfused regions, craters, sagging metal seams, faulty fusions, flooding of the melted channel, and the specific: surface flaws, unsatisfactory geometry of a seam, discontinuities of a material, unfavourable structure, deteriorated properties, and voids (closed cavities).

A welding defect is any flaw that compromises the usefulness of a weldment. There is a great variety of welding defects. Welding imperfections are classified according to ISO 6520 [3] while their acceptable limits are specified in ISO 5817 [4] and ISO 10042 [5]. According to the American Society of Mechanical Engineers, welding defect causes are broken down as follows: $45 \%$ poor process conditions, $32 \%$ operator error, $12 \%$ wrong technique, $10 \%$ incorrect consumables, and $5 \%$ bad weld grooves.

Some of these flaws cannot often be detected with traditional non-destructive techniques (NDT). Nondestructive techniques in weld joint area are commonly used to control and diagnostic of welding processes. Nondestructive techniques try to ensure that the welds are free of unacceptable defects. In the last years considerable efforts have been devoted to providing a reliable monitoring system to perform a real-time analysis of the process and detecting the appearance of possible weld flaws [6]. The non-destructive techniques are an effective tool to detect the damage through all phases of its life cycle. Defects analysis is important in technical diagnostics which includes assessment of the technical condition of a machine's parts by studying the properties of its work processes. Failure of machine parts can be avoided by properly welded joints and through root cause analysis of defects maintenance of machine parts is reduced. The diagnostics is important for mining, metallurgy, processing industry, and materials science $[7 \div 10]$.

The most traditional non-destructive technique is Visual Inspection. Prior to any welding, the materials should be visually inspected to see if they are clean and correctly aligned, machine settings and filler selection should be checked, etc. Visual Inspection of all completed welds should be carried out under good lighting and excess penetration can often be visually detected.

Equally often we use Liquid Penetrant Inspection. Serious cases of surface cracking can be detected by the naked eye but for most cases some type of aid is needed. We need to cover the surface with a liquid dye that has good penetrating properties. After adequate penetration time, the excess penetrant is removed and a developer is applied. The developer helps to draw the penetrant out of the flaw so that an invisible indication becomes visible for the inspector. The main advantages of this method are the speed of the test and the low cost. Disadvantages include the detection of only surface flaws. The inspection should be made on a smooth clean surface where excessive 
penetrant can be removed prior to being developed and operator experience is quite valuable.

Modern non-destructive techniques include X-Ray Inspection which allows detecting sub-surface cracks and inclusions. It is an expensive method, but very powerful, and e.g. $100 \%$ of weld joints will be carried out in nuclear power plants.

Surface and sub-surface defects can also be detected by Ultrasonic Testing (UT). This involves directing a high frequency sound beam through the base metal and weld on a predictable path. When the beam strikes a discontinuity, some of it is reflected back. This reflected beam is received, amplified, and processed, and from the time delay, the location of the flaw is estimated. Porosity, however, in the form of numerous gas bubbles, causes a lot of low amplitude reflections which are difficult to separate from the background noise.

Eddy Current Testing (ET) - the wire coil produces an alternating magnetic field around itself. When the coil approaches a conductive material, currents opposed to the ones in the coil (eddy currents) are induced in the material. Variations in the electrical conductivity and magnetic permeability of the test object, and the presence of defects causes a change in eddy current and a corresponding change in phase and amplitude that can be detected by measuring the impedance changes in the coil. This method is limited to conductive materials and depth of tested surfaces.

The newest technique is Computed Tomography (CT). It is a very powerful and universal method with which we can find and measure cracks or pores inside the weld joint. CT allows testing any kind of weld joint e.g. butt or tee. The limit of this method is possibility of penetration of the tested object by X-rays.

The aim of the paper is to present advantages and disadvantages of methods of weld inspection. Although the approach is of general applicability, the paper demonstrates in the specific context three kinds of methods of inspection of austenitic stainless steel welds joints. Presented research has been carried out for the most popular weld diagnostics methods in the industry.

\section{Material and methods}

The welding method used was orbital welding which is a mechanized version of the tungsten inert gas arc welding (TIG) process. This method is used to weld pipes or stationary tubes. The tungsten electrode contained in the weld head rotor rotates (orbits) around the weld joint circumference. The welding speeds were $125 \mathrm{~mm} / \mathrm{min}$. The TIG process can be either a fusion (autogenous) process in which the edges of the weld joint are heated by the arc and fused together without the addition of filler material to the weld pool or may use an additional filler material. The welded material was pipes $\varnothing 50 \times 1,5$ of austenitic stainless steel 1.4301 (DIN EN 10088-1). The elemental composition of the welded material is given in Tab. 1.

Table 1 Chemical composition of 1.4301 austenitic stainless steel / wt.

\begin{tabular}{|c|c|c|c|c|c|c|c|}
\hline$\% \mathrm{C}$ & $\% \mathrm{Si}$ & $\% \mathrm{Mn}$ & $\% \mathrm{P}$ & $\% \mathrm{~S}$ & $\% \mathrm{Cr}$ & $\% \mathrm{Ni}$ & $\% \mathrm{~N}$ \\
\hline 0,07 & 1,00 & 2,00 & 0,045 & 0,015 & $\begin{array}{c}17,50 \\
\text { to } \\
19,50\end{array}$ & $\begin{array}{c}8,00 \\
\text { to } \\
10,50\end{array}$ & 0,11 \\
\hline
\end{tabular}

Surface profilometry as a method of topographic inspection was performed using an Infinite Focus Measurement Machine (IFM). The IFM is an optical 3D measurement device which allows the acquisition of data sets at a high depth of focus. The IFM method allows for the capture of images with a lateral resolution down to $400 \mathrm{~nm}$, and a vertical resolution down to $20 \mathrm{~nm}$. The IFM 4.2 software version was used to collect and present the measurement data. The surface profilometry analysis was carried out in the OUTech Surface Integrity Lab. The X-ray tests were carried out using RTG SITE - XS D2254.

Table 2 X-ray CT technical data

\begin{tabular}{|l|c|c|}
\hline \multicolumn{2}{|c|}{ X-ray CT system XTH XT H 225 ST } \\
\hline \multirow{2}{*}{$\begin{array}{l}\text { Operating voltage and power } \\
\text { output of X-ray source }\end{array}$} & $\begin{array}{c}\text { Reflection t. } \\
\text { Reflection }\end{array}$ & $225 \mathrm{kV} / 225 \mathrm{~W}$ \\
\cline { 2 - 3 } & $\begin{array}{c}\text { Transmission } \\
\text { source }\end{array}$ & $180 \mathrm{kV} / 20 \mathrm{~W}$ \\
\hline $\begin{array}{l}\text { X-ray focal size } \\
\text { (reflex. mode / trans. mode) }\end{array}$ & $<3 \mu \mathrm{m} /<1 \mu \mathrm{m}$ \\
\hline $\begin{array}{l}\text { Max. weight / height and diameter } \\
\text { of the scanned samples }\end{array}$ & $50 \mathrm{~kg} / \mathrm{c} .0,30 \mathrm{~m} / 0,30 \mathrm{~m}$ \\
\hline $\begin{array}{l}\text { Max. X-raying thickness of the } \\
\text { analysed samples }\end{array}$ & \multicolumn{2}{|c|}{$237 \mathrm{~kg} / \mathrm{m}^{2}$} \\
\hline $\begin{array}{l}\text { X-ray detectors } \\
\text { (16-bit contrast resolution) }\end{array}$ & $\begin{array}{c}\text { Flat Panel Detector } \\
(200 \text { micron/pixel, } 4 \text { mil. Px })\end{array}$ \\
\hline
\end{tabular}

a)

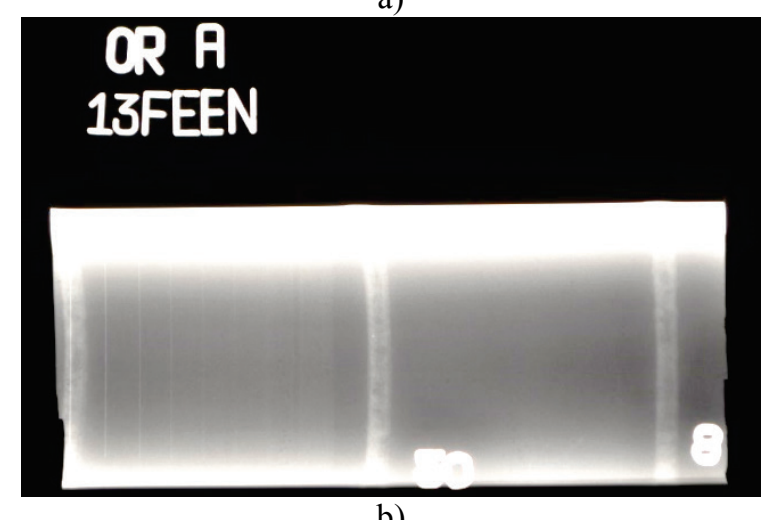

b)

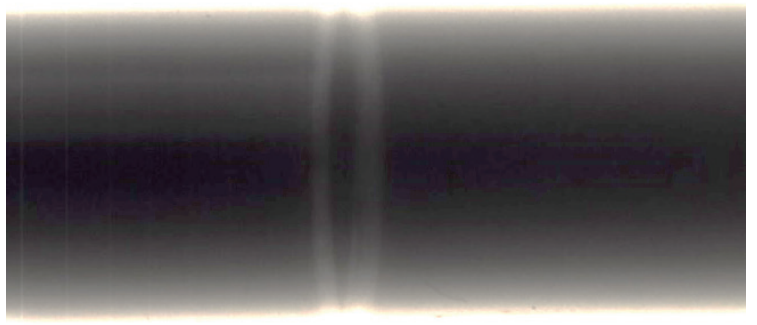

Figure 1 X-ray images of a weld joint

The industrial X-ray micro-computerized tomograph XT H 225 ST Nikon Metrology NV was used for the analysis of influencing the structure of the material around the welded thin-walled tubes under different welding conditions. The device is installed at the Institute of Geonics AS CR. It is a fully automated system with a rotary microfocal scanning system equipped with X-ray sources emitting conical beam. Department's tomography laboratory is also equipped with appropriate reconstruction and visualization software. Basic technical 
data of the equipment used are listed in the following Tab. 2 .

X-ray CT is one of the methods of both quantitative and qualitative analysis of different types of materials utilizing different properties of the X-ray interaction with the own mass of the materials studied. In particular, they have the ability to penetrate different kinds of materials with differing degrees of phasing out depending on the properties of the studied object, especially on its density. For the reconstruction of CT volumes, consisting of a single voxel, a set of radiographic $2 \mathrm{D}$ projections of the known rotation angle of the object during its rotation by $360^{\circ}$ must be purchased during the scan process. Radiographic image shows a 2D map showing the pixels in different shades of grey (grey scale range is determined by the type of detector and the bit depth of 8 bit, 16 bit, etc.). The intensity of both unattenuated and attenuated $\mathrm{X}$ rays passing through the object studied. For a sufficient number of radiographic projections, CT volume of an object is then reconstructed (calculated) using computational algorithms.

The tested samples (dimensions $10 \times 1,6 \times 50 \mathrm{~mm}$ ) were scanned and analysed using an X-ray source transmitted to a weld area within a distance of approximately one of its width. Second acceleration voltage was set to $165 \mathrm{kV}$ (indicating hardness ray). Radiation current was set to $60 \mu \mathrm{A}$. 3,142 radiographic projections were used in the process of scanning; for one screening, 4 radiographic images were performed with exposure to $2829 \mathrm{~ms}$. Voxel size of the resulting tomographic volume is represented by the value of about $5 \mu \mathrm{m}$. The total time of one CT scan was approximately 12 hours. Using the software VG Studio Max, visualization and evaluation of the reconstructed CT volumes of the individual specimens was then performed. In case of specimens CT inferred material change can be analysed. It is possible, but it has been observed that such defects as pores and other discontinuities were found in the vicinity of weld defects in the nearby weld material.

a)

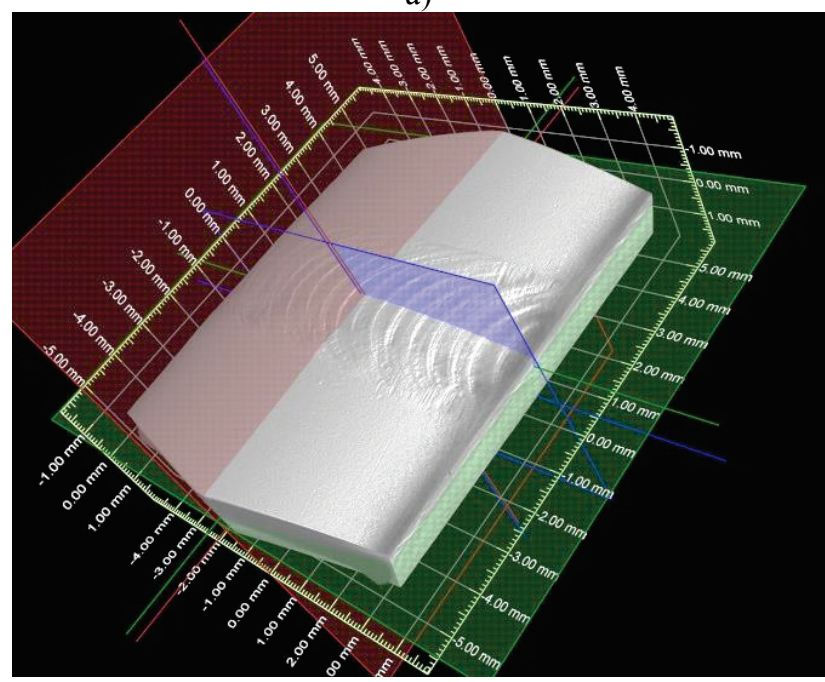

b)

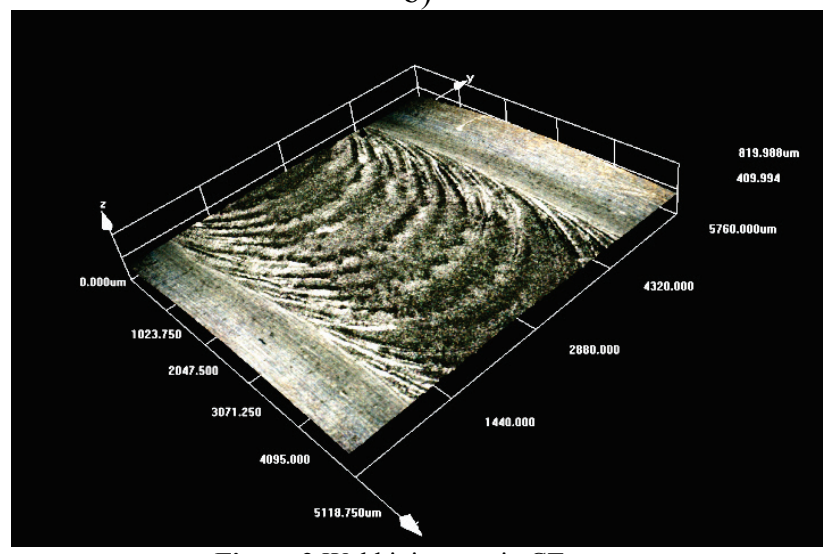

Figure 2 Weld joint area in CT scan

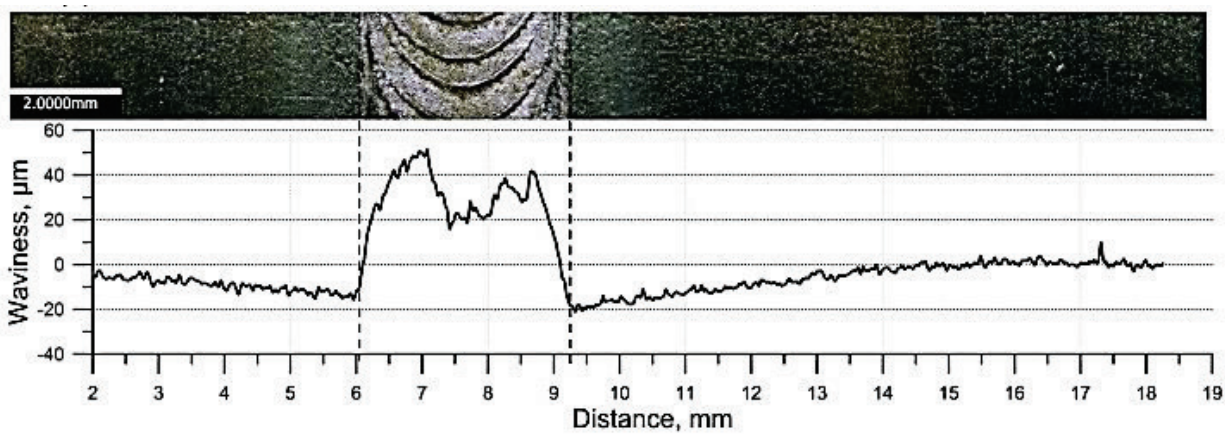

Figure 3 Surface morphology and waviness of weld area

\section{Industrial approach}

The welded material is austenitic stainless steel. Austenitic welds are anisotropic and inhomogeneous. Many different microstructures arise in HAZ under the influence of the weld thermal cycle [11]. This stainless steel is widely used for many industrial applications due to its unique properties. Good combination of its mechanical properties (high strength and toughness) and corrosion resistance makes it of great interest for a wide range of applications [12], especially in the oil, food, chemical and safety-critical industries like power or oil industry and gas plants. In all these industries, non- destructive techniques inspection is used to ensure that the plant enters service without any defects. Regular inspections are used to verify that no defects have grown to an unacceptable size [13]. The most important defect is cracks, particularly those having a sizeable through-wall extent. This defect is related to the metallographic structure of the weld joint. According to Tsisar et al. [14] martensitic steels have a tendency to cause weld cracking during cooling when hard brittle martensite is formed. Kim et al. [15] investigated the effects of shielding gas on the pitting corrosion of hyper duplex stainless steel welds and reported that the pitting resistance of a heat-treated solution welded with a combination of $\mathrm{Ar}$ and $\mathrm{N}_{2}$ as the 
shielding gas is greatly increased due to an increase of austenite in the weld material and HAZ (heat affected zone). Furthermore, many researchers have engaged in research on the welding process of stainless steels $[16 \div 18]$, but those publications did not mention geometrical parameters of Surface Morphology. Krolczyk et al. [19] analysed surfaces of welded joints in steel pipes using an optical 3D measurement system to determine their morphology and topographic parameters. They established that pollution of the argon shield gas with oxygen did not influence the width of the HAZ. The measurement of surface morphology parameters enabled the selection of a higher quality surface. This publication, however, analyses weld join only from a metrological point of view. According to Connolly et al. [13] radiography finds cracks most efficiently only if the beam of radiation aligns well with the plane of the crack, whereas ultrasound is more effective when the beam aligns normally to the crack. In practice, in this case CT and profilometry are unused but there is much interest in developing other methods in order to avoid the use of radiography, particularly for in-service inspection in industries.

\section{Recent trends}

Another strongly growing branch of research is microtomography. It allows, similarly to the measuring tomograph, imaging of the internal structure of the object [20]. However, the main difference between these devices is the possibility of magnification of the measured object. Microtomography allows observation of the internal structure of the material up to the individual grains [21, 22]. One of the conditions necessary for the implementation of this measure is to reduce the power of $\mathrm{X}$-rays, and this creates the need to reduce the dimensions of the object being measured. These devices provide a very detailed observation of the internal structure of the object. However, in most cases, even though it is a nondestructive measurement method, it is necessary to prepare a relatively small segment to represent the whole object.

X-ray CT measuring scanners allow for a much broader imaging of the measured object. It is possible to obtain both the $3 \mathrm{D}$ images of the object and evaluation of its geometry, for internal as well as for external surface. Appropriate adjustment of parameters also allows the assessment of the internal structure of the material and measurement of the size and distribution of pores in the cast or distribution of fibres in the composite [23]. In parallel there are developing devices, similar to microtomographs, that allow for the observation of metallographic structure, but their limitations are the requirement of the objects studied being of small sizes.

One of the obstacles in the application of modern research methods is the high cost of equipment. However, the development of these systems leads us to believe that, in some time, they will become more accessible as well as mobile devices for scanning X-ray welds, which today can be considered almost a standard method of control.

\section{Discussion}

Coordinate measuring technique is the field of metrology of geometrical quantities, which is rapidly developing at present and is applied in many fields of technology [24, 25]. A wide range of methods can be qualified for this technique on account of the nature of the measurement - collection of coordinates describing position of individual measuring points. A common feature of these methods is the possibility of estimation of the surface only - the surface which can be seen or touched by a gauging point $[26 \div 28]$. Computer tomography $(\mathrm{CT})$ has recently allowed extending the measuring possibilities. In this method, objects are Xrayed. CT scanners have been known in medicine for a long time, but they have been only used for about 10 years as a tool for technical imaging of $3 \mathrm{D}$ objects. The image from the CT scanner allows for estimation of both the geometry of the manufactured product as well as of internal closed surfaces. It also allows for analysis of pores in the interior material or for estimation of deformation of subassemblies during joining [29, 30].

There is a broad spectrum of methods belonging to the group of non-destructive testing techniques for welded joints. The use of these methods has been indispensable since altering the structure of the weld precludes its further use. Besides computer tomography, some other methods are applied for that purpose, including screening of welds using X-rays and profilometry method. The disadvantage of CT is the stationary nature of work and the significant cost of the device. The advantage of this technique is detection of the measuring point coordinates that describe the examined object [31]. The obtained data are digitally processed which allows to obtain information on the actual dimension deviations. Aside from information on the surface, in case of CT we can get data on the internal section as well. This allows detecting pores or estimating the geometry of closed surface as well as calculating the position and volume of the found material discontinuities. Inspection by a CT scanner is based on the measurement of radiation absorption which penetrates the object. If the condition of the object penetration is fulfilled, the X-ray CT allows for measurement and control of any butt, filled, edge, point, and plug weld [32, 33].

Devices that inspect welds using X-rays are usually mobile. They can be put on any weldment, but do not allow for checks of the filled welds. X-ray penetration of the weld allows for detection of discontinuities that represent pores or inclusions. It is possible to visually assess their size, but it is not possible to measure the dimension, volume, and location of such a phenomenon accurately. The measurement of the weld profile is also a non-invasive and non-contact method. Properly made welded joint is characterized by equal and symmetrical shape of both the weld and heat affected zone. Assessing the measured profile with this method means that the data about the correctness of the connection is obtained in a short time; it is, however, an assessment which does not include information on the internal structure of the weld. In industrial practice, measurement with mobile devices that allow for fast and sufficiently accurate control of the weld joint can be used successfully. Devices such as CT 
present very wide measurement capabilities, but one of the limits is the ability to penetrate the object. When the power of the X-ray tube increases, the sharpness unfavourably decreases which results in decrease of measurement accuracy. Therefore, it is very difficult to say which device is the most appropriate to use - it depends strongly on the application of research. However, it can be concluded that the CT scanner allows for both detection of pores and voids as an X-ray mobile device, as well as for the reconstruction of the measured data to obtain a picture of the weld as in the method of profiling. Among the analysed methods of topographic inspection of weld joint surface, profilemetry is the most appropriate for industrial applications. Surface profilometry has been known for many years as a method of topography inspection. Koszela et al. [34] showed textured cylinder liners surface topographies for visualization of oil pockets array on a machined surface. Parthasarathi et al. [35] investigated characterization of worn surface topography in the prototype fast breeder reactor. Safara, Nosar and Olsson [36] presented 3D surface topography images and surface profiles behind the initial stages of material transfer between stainless steel and tool steel in metal forming operations. In order to establish effective quality control of the weld zone, an extensive investigation has been recommended, including the clarification of the deterioration problems of the surface weld joints, which is important in practical use [37].

\section{Conclusions}

The paper presents the measurement results for three different measuring devices. The estimation of different types of methods was performed, which allows to look at the obtained values more widely. Three types of measuring devices allow effective measurement of the weld joint area, which has been presented in this paper. We cannot explicitly conclude which device is more appropriate to apply, because each of these devices is characterized by many advantages and drawbacks.

- Portable X-ray allows controlling the object in practically any environment, but it is only possible to obtain a 2D image with it.

- CT measurement enables us to obtain a 3D image for both external surfaces and internal structure. However, measurements are stationary and the size of the object being measured is the limitation of this method.

- The profilometric method allows for very accurate measurement of the external shape of the element, but does not allow for evaluation of the internal structure of the weld.

\section{Acknowledge}

This article has been written within the project of the Institute of Clean Technologies for Mining and Utilisation of Raw Materials for Energy Use, reg. no. CZ.1.05/2.1.00/03.0082, which is supported by the Research and Development for Innovations Operational Programme financed by the Structural Funds of the European Union and the state budget of the Czech Republic. The presented work was also sustained by a project to support long-term conceptual development of research organizations RVO: 68145535.

\section{References}

[1] Chatterjee, S.; Chatterjee, R.; Pal, S.; Pal, K.; Pal, S.K. Adaptive chirplet transform for sensitive and accurate monitoring of pulsed gas metal arc welding process. // The International Journal of Advanced Manufacturing Technology. 60, 1-4(2012), pp. 111-125. DOl: 10.1007/s00170-011-3597-7

[2] Sazonov, Y. I. Problems of engineering diagnostics of electron-beam welding. // Russian Journal of Nondestructive Testing. 42, 12(2006), pp. 823-836. DOl: $10.1134 / \mathrm{S} 1061830906120084$

[3] ISO 6520-1:2007: Welding and allied processes Classification of geometric imperfections in metallic materials - Part 1: Fusion welding.

[4] ISO 5817:2014: Welding - Fusion-welded joints in steel, nickel, titanium and their alloys (beam welding excluded) Quality levels for imperfections.

[5] ISO 10042:2005: Welding - Arc-welded joints in aluminium and its alloys - Quality levels for imperfections.

[6] Rodriguez-Cobo, L.; Mirapeix, J.; Ruiz-Lombera, R.; Cobo, A.; López-Higuera, J. M. Fiber Bragg grating sensors for on-line welding diagnostics. // Journal of Materials Processing Technology. 214, 4(2014), pp. 839-843. DOI: 10.1016/j.jmatprotec.2013.11.026

[7] Mazurkiewicz, D. Computer-aided maintenance and reliability management systems for conveyor belts. // Eksploatacja I Niezawodnosc - Maintenance and Reliability. 16, (2014), pp. 377-382.

[8] Dewangan, S.; Chattopadhyaya, S.; Hloch, S. Wear assessment of conical pick used in coal cutting operation. // Rock Mechanics and Rock Engineering. 2014. DOI: 10.1007/s00603-014-0680-z.

[9] Glowacz, A. Recognition of Acoustic Signals ofLoadedSynchronous Motor Using FFT, MSAF-5 and LSVM. // Archives of Acoustics. 40, (2015), pp. 197-203. DOI: 10.1515/aoa-2015-0022

[10] Glowacz, A.; Glowacz, A.; Glowacz, Z. Recognition of monochrome thermal images of synchronous motor with the application of quad tree decomposition and backpropagation neural network. // Eksploatacja i Niezawodnosc - Maintenance and Reliability. 16, (2014), pp. 92-96.

[11] Samardzić, I.; Stoic, A.; Kozak, D.; Kladaric, I.; Dunder, M. Application of Weld Thermal Cycle Simulator in Manufacturing Engineering. // Journal of Manufacturing and Industrial Engineering. 12, 1-2(2013), pp. 7-11. DOI: 10.12776/mie.v12i1-2.177

[12] Krolczyk, G. M.; Legutko, S. Experimental analysis by measurement of surface roughness variations in turning process of duplex stainless steel. // Metrology and Measurement Systems. XXI, 4(2014), pp. 759-770. DOI: 10.2478/mms-2014-0060

[13] Connolly, G. D.; Lowe, M. J.; Temple, J. A. G.; Rokhlin, S. I. The application of Fermat's principle for imaging anisotropic and inhomogeneous media with application to austenitic steel weld inspection. // Proceedings of the Royal Society A: Mathematical, Physical and Engineering Science, (2009). DOI: 10.1098/rspa.2009.0272

[14] Tsisar, V.; Kondo, M.; Muroga, T.; Nagasaka, T.; Matushita, I. Morphological and compositional features of corrosion behavior of SUS410-SUS410, SUS316-SUS316 and SUS410-SUS316 TIG welded joints in Li. // Fusion Engineering and Design. 87, 4(2012), pp. 363-368. DOI: 10.1016/j.fusengdes.2012.03.014

[15] Kim, S-T.; Jang, S-H.; Lee, I-S.; Park, Y-S. Effects of solution heat-treatment and nitrogen in shielding gas on the 
resistance to pitting corrosion of hyper duplex stainless steel welds. // Corrosion Science. 53, 5(2011), pp. 19391947. DOI: 10.1016/j.corsci.2011.02.013

[16] Zhang, Z.; Wang, Z.; Jiang, Y.; Tan, H.; Han, D.; Guo, Y.; $\mathrm{Li}$, J. Effect of post-weld heat treatment on microstructure evolution and pitting corrosion behavior of UNS S31803 duplex stainless steel welds. // Corrosion Science. 62, (2012), pp. 42-50. DOI: 10.1016/j.corsci.2012.04.047

[17] Yajiang, L.; Haijun, M.; Juan, W. A study of crack and fracture on the welding joint of $\mathrm{Fe} 3 \mathrm{Al}$ and $\mathrm{Cr} 18-\mathrm{Ni} 8$ stainless steel. // Materials Science and Engineering: A. 528, 13-14(2011), pp. 4343-4347. DOl: 10.1016/j.msea.2011.02.070

[18] Chern, T-S.; Tseng, K-H.; Tsai, H-L. Study of the characteristics of duplex stainless steel activated tungsten inert gas welds. // Materials \& Design. 32, (2011), pp. 255263. DOI: $10.1016 /$ j.matdes.2010.05.056

[19] Krolczyk, G.M.; Nieslony, P.; Krolczyk, J.B.; Samardzic, I.; Legutko, S.; Hloch, S.; Barrans, S.; Maruda, R.W. Influence of argon pollution on the weld Surface Morphology. // Measurement. 70, (2015), pp. 203-213. DOI: 10.1016/j.measurement.2015.04.001

[20] Landis, E. N.; Keane, D. T. X-ray microtomography Tutorial review. // Materials Characterization. 61, (2010), pp. 1305-1316. DOI: 10.1016/j.matchar.2010.09.012

[21] Dietrich, S.; Koch, M.; Elsner, P.; Weidenmann, K. Measurement of Sub-Surface Core Damage in Sandwich Structures Using In-situ Hertzian Indentation during X-ray Computed Tomography. // Experimental Mechanics. 54 (2014), pp. 1385-1393. DOI: 10.1007/s11340-014-9902-2

[22] Diffraction Contrast Tomography Unlocking Crystallographic Information from Laboratory X-ray Microscopy. // Carl Zeiss Microscopy GmbH, Germany, 2014.

[23] Moreno-Atanasio, R. A.; Williams, R.; Jia, X. Combining $\mathrm{X}$-ray microtomography with computer simulation for analysis of granular and porous materials. // Particuology. 8 (2010), pp. 81-99. DOI: 10.1016/j.partic.2010.01.001

[24] Hartmann, W.; Weckenmann, A. Function-Oriented Dimensional Metrology - More than Determining Size and Shape. // Proceedings SENSOR 2013, 01 (2013), pp. 285290.

[25] Gapinski, B.; Wieczorowski, M.; Marciniak-Podsadna, L.; Dybala, B.; Ziolkowski, G. Comparison of Different Method of Measurement Geometry using CMM, Optical Scanner and Computed Tomography 3D. // Procedia Engineering. 69 , (2014), pp. 255-262. DOI: 10.1016/j.proeng.2014.02.230

[26] Wieczorowski, M.; Cellary, A.; Majchrowski, R. The analysis of credibility and reproducibility of surface roughness measurement results. // Wear. 269, 5-6(2010), pp. 480-484. DOI: 10.1016/j.wear.2010.05.003

[27] Gapinski, B.; Rucki, M. The Roundness Deviation Measurement with CMM. // Proceedings of IEEE Workshop on Advanced Methods for Uncertainty Estimation Measurement AMUEM-2008, Sardagna Trento, Italy, (2008), pp. 108-111. DOl: 10.1109/AMUEM.2008.4589944

[28] Pawlus, P.; Reizer, R.; Wieczorowski, M. The Analysis of Directionality of Honed Cylinder Liners Surfaces. // Scanning. 36, (2014), pp. 95-104. DOI: 10.1002/sca.21101

[29] Carmignato, S.; Savio, E. Traceable volume measurements using coordinate measuring systems. // CIRP Annals Manufacturing Technology. 60, 1(2011), pp. 519-522. DOI: 10.1016/j.cirp.2011.03.061

[30] Dovica, M.; Vegh, A. Comparison of the Cylindricity Deviation Using Different Evaluation Methods. // American Journal of Mechanical Engineering. 1, 7(2013), pp. 339342. DOI: 10.12691/ajme-1-7-37
[31] Kruth, J. P.; Bartscher, M.; Carmignato, S.; Schmitt, R.; De Chiffre, L.; Weckenmann, A. Computed tomography for dimensional metrology. // CIRP Annals - Manufacturing Technology. 60, (2011), pp. 821-842. DOI: 10.1016/j.cirp.2011.05.006

[32] Kramer, P.; Weckenmann, A. Computed tomography in quality control: chances and challenges. // Proceedings of the Institution of Mechanical Engineers; Part B: Journal of Engineering Manufacture. 227, (2013), pp. 634-642. DOI: $10.1177 / 0954405413479849$

[33] Wieczorowski, M.; Gapinski, B. X-ray CT in Metrology of Geometric Feature. // Acta Tehnica Corviniensis - Bulletin of Engineering. VII, 1(2014), pp. 95-100.

[34] Koszela, W.; Pawlus, P.; Rejwer, E.; Ochwat, S. Possibilities of oil pockets creation by the burnishing technique. // Archives of Civil and Mechanical Engineering. 13, (2013), pp. 465-471. DOl: 10.1016/j.acme.2013.03.004

[35] Parthasarathi, N. L.; Borah U.; Albert, S. K. Effect of temperature on sliding wear of AISI $316 \mathrm{~L}(\mathrm{~N})$ stainless steel - Analysis of measured wear and surface roughness of wear tracks. // Materials \& Design. 51, (2013), pp. 676-682. DOI: 10.1016/j.matdes.2013.04.050

[36] Safara Nosar, N.; Olsson, M. Influence of tool steel surface topography on adhesion and material transfer in stainless steel / tool steel sliding contact. // Wear. 303, (2013), pp. 30-39. DOI: 10.1016/j.wear.2013.02.015

[37] Özyürek, D. An effect of weld current and weld atmosphere on the resistance spot weldability of 304L austenitic stainless steel. // Materials \& Design. 29, (2008), pp. 597603. DOI: 10.1016/j.matdes.2007.03.008

\section{Authors' addresses}

\author{
Jolanta B. Krolczyk \\ Grzegorz, M. Krolczyk \\ Piotr Nieslony \\ Opole University of Technology, \\ 76 Proszkowska Street, 45-758 Opole, Poland \\ E-mail: j.krolczyk@po.opole.pl \\ E-mail: g.krolczyk@po.opole.pl \\ E-mail: p.nieslony@po.opole.pl
}

\section{Bartosz Gapiński}

Stanislaw Legutko

Faculty of Mechanical Engineering and Management,

Poznan University of Technology,

3 Piotrowo Street, 60-965 Poznan, Poland

E-mail: bartosz.gapinski@put.poznan.pl

E-mail: stanislaw.legutko@put.poznan.pl;

\section{Ivan Samardžić}

Mechanical Engineering Faculty in Slavonski Brod,

J. J. Strossmayer University of Osijek,

Trg Ivane Brlić Mažuranić 2, 35000 Slavonski Brod, Croatia

E-mail: ivan.samardzic@unios.hr

\section{Radoslaw W. Maruda}

Faculty of Mechanical Engineering, University of Zielona Gora, 4 Prof. Z. Szafrana Street, 65-516 Zielona Gora, Poland E-mail: r.maruda@ibem.uz.zgora.pl;

\section{Kamil Soucek}

Lubomir Stas

Institute of Geonics AS CR, v. v. i.

Studentska 1768, Ostrava-Poruba, 708 00, Czech Republic

E-mail: kamil.soucek@ugn.cas.cz

E-mail: lubomir.stas@ugn.cas.cz

\section{Yashar Javadi}

Department of Mechanical Engineering, Semnan Branch,

Islamic Azad University, Semnan, Iran

E-mail: yashar_javadi@yahoo.com 